\title{
Boticas e o "Vinho dos Mortos": reforçar a identidade cultural do território na experiência de enoturismo
}

\author{
Boticas and the "Wine of the Dead": reinforcing cultural \\ territorial identity in wine tourism experiences
}

\section{Boticas y el "vino de los muertos": fortalecer la identidad cultural del territorio en la experiencia del turismo de vino}

Josefina Olívia Salvado ${ }^{1}$

Resumo: Propósito justificado do tema: O território de Boticas (Norte Portugal), embora de baixa densidade populacional é visto como um espaço de valorização do património cultural, ao integrar de forma harmoniosa o seu ecossistema de enoturismo através de várias dinâmicas potenciadoras dos recursos endógenos, resultando num reforço da identidade e singularidade culturais. Objetivo: O objectivo deste trabalho é mostrar o "vinho dos mortos" como uma tradição vitivinícola peculiar e um símbolo da astúcia e sobrevivência do povo de Boticas, tendo surgido no período da 2 a Invasão Francesa (1808). O seu nome resultou do facto do vinho ter sido enterrado no chão das adegas, no saibro, debaixo das pipas e dos lagares para salvaguardar o património do saque dos soldados franceses. Design/Metodologia e abordagem: No estudo foram utilizadas duas metodologias qualitativas: MatrizPCl (Matriz Património Cultural Imaterial) para inventariação dos recursos endógenos, seguindo as orientações da UNESCO quanto à "Salvaguarda de Património Cultural" e o modelo dos 6 A's de Buhalis para o reconhecimento dos atributos do destino turístico e sustentar a propostas de criação de valor na experiência de Enoturismo. Resultados: Os resultados mostram Boticas como um espaço geográfico multifuncional onde as suas características/atributos endógenos asseguram um posicionamento privilegiado e competitivo no quadro do turismo de vinho. Originalidade do documento: Este trabalho é original quanto ao tema e enquadramento.

Palavras-chave: Enoturismo. Ecossistema. Património cultural. Vinho dos Mortos. Boticas.

Abstract: Justified purpose of the topic: The territory of Boticas (in the North of Portugal) has a low population density and is considered a powerful space of cultural heritage. Objective: The wine tourism ecosystem strategy will involve several dynamics that can enhance endogenous resources, resulting in a reinforcement of identity and Cultural uniqueness. The "wine of the dead" is a surviving symbolic wine tradition connected with the second French Invasion of Portugal (1808). The expression "Wine of the dead" derived from the ancient practice of burying the bottles underneath cellar floors to safeguard property from the French soldiers. Design / Methodology

\footnotetext{
${ }^{1}$ Doutora em Turismo pela Universidade de Aveiro (UA). Investigadora da GOVCOPP - Unidade de Investigação Governança, competitividade e Politicas Públicas da Universidade de Aveiro. Concepção e desenho do trabalho científico; Aquisição e Interpretação dos dados. Redação do trabalho.
}

Artigo recebido em: 10/02/2017. Artigo aceito em: 20/04/2017. 
and approach: Two qualitative methodologies were used: MatrizPCl (Intangible Cultural Heritage Matrix), following UNESCO's guidelines on "Safeguarding Cultural Heritage" for endogenous resources inventory, and Buhalis' six A's framework for the analysis of tourism destinations. Results: The results show Boticas as a multifunctional geographical space where its endogenous characteristics / attributes ensure a privileged and competitive position within the framework of wine tourism. Originality of the document: This work is original on the theme and framework.

Keywords: Wine tourism Ecosystem. Cultural Heritage. Wine of the dead. Boticas.

Resumen: Justificativo del tema: El territorio de Boticas (Norte de Portugal), a pesar de la baja densidad de población, es visto como un espacio con valores para el patrimonio cultural, integrando armoniosamente su ecosistema con el turismo del vino a través de diversas dinámicas potenciadoras de los recursos locales, dando como resultado un fortalecimiento de la identidad cultural y la singularidad de la cultura local. Objetivo: El objetivo de este trabajo es mostrar el "vino de los muertos" como una tradición peculiar de las marcas de vino y un símbolo de la astucia y la supervivencia de las personas de Boticas, surgido en el período de la segunda invasión francesa (1808). Su nombre se debe al hecho de que el vino ha sido colocado en el suelo de la bodega, en tierra batida, bajo las tuberías y los molinos para salvaguardar del saqueo de los soldados franceses. Diseño/Metodología y enfoque: en el estudio cualitativo se utilizaron dos metodologías: MatrizPCI (matriz de patrimonio cultural intangible) para el inventario de los recursos locales, siguiendo las directrices de la UNESCO sobre la "protección del patrimonio cultural" y el modelo de los "6 As" de Buhalis, para el reconocimiento de los atributos del destino turístico y sostener las propuestas de creación de valor en la experiencia del turismo de vino. Resultados: Los resultados muestran Boticas como una zona geográfica multifuncional donde sus características/atributos locales garantizan una posición competitiva privilegiada en el turismo de vino. La originalidad del documento: Este trabajo es único por su tema y encuadre.

Palabras clave: Turismo de Vino. Ecosistema. Patrimonio cultural. Vino de los muertos. Boticas.

\section{INTRODUÇÃO}

Boticas é um destino turístico que dispõe de ativos territoriais endógenos singulares e um espaço geográfico que, embora de baixa densidade populacional, tem na sua génese uma dimensão edificada na cultura e identidade, que importa valorizar. $O$ estudo incide no turismo de vinho integrado no espaço-território do concelho de Boticas, que corresponde a uma parte da antiga terra do Barroso, cuja paisagem será caracterizada na secção 2. Asero \& Patti (2009) refere o vinho como um "territorial intensive product", uma vez que contém uma forte referência à identidade territorial em que é produzido. $\mathrm{O}$ vinho como um produto cultural, tem vindo a edificarse como um ecossistema catalisador do desenvolvimento dos territórios.

O conceito de ecossistema associado ao turismo de vinho será detalhado na secção 3 , apresentando os seus componentes principais, 0 Território, o Turismo e Cultura vitivinícola, que surgem coligados com dinâmicas culturais, de origem material, imaterial e de sociabilidade. No caso de Boticas e do "Vinho dos Mortos" é reconhecido o enoturismo como um importante veículo para um incremento regional sustentável, ao incorporar um conjunto de dinâmicas de identificação, integração e valorização dos recursos endógenos e culturais na oferta turística; ao explorar de forma criativa e inovadora a multifuncionalidade da paisagem rural e ao criar experiências culturais de enoturismo que envolvem todos os stakeholders locais. De acordo com Brunet (1990), no espaço-território as relações sociais entre os atores locais, fazem surgir um sentimento de pertença à identidade construída, criando laços de solidariedade entre eles.

Duas metodologias qualitativas foram aplicadas no trabalho, detalhadas na secção 4 , a 
MatrizPCI (Matriz Património Cultural Imaterial) para inventariação dos recursos endógenos, seguindo as orientações da UNESCO quanto à "Salvaguarda de Património Cultural" e o modelo dos 6 A's de Buhalis para o reconhecimento dos atributos do destino turístico e sustentar a propostas de criação de valor na experiência de Enoturismo.

Na secção 5 apresenta-se uma proposta de integração do produto "Vinho dos Mortos" na estratégia de visitação de Boticas, como incentivo da criação de valor de uma oferta turística cultural diferenciada. Verifica-se que Boticas é um espaço geográfico multifuncional onde os seus recursos endógenos e culturais permitem assegurar um posicionamento privilegiado e competitivo no quadro do turismo de vinho. O sucesso da implementação destas dinâmicas assenta em estratégias de coopetição onde todos os intervenientes devem construir uma visão e missão comuns, encorajando ao desenvolvimento e à sustentabilidade dos espaços-território.

\section{CARACTERIZAÇÃO DO ESPAÇO-TERRITÓ- RIO DE BOTICAS}

\subsection{Terra de Barroso - um território de baixa densidade}

A construção territorial de Portugal integra os condicionantes das sociedades e da natureza, não se desenvolvendo de forma homogénea. Pecqueur (2000) refere a existência de dois tipos de territórios, um estabelecido por decisão político-administrativa, num processo "topdown" de decisão, definindo políticas de desenvolvimento para a região e outro construído, chamado espaço-território, formado a partir de um encontro de atores sociais, que procura identificar e resolver um problema comum. De acordo com Oliveira Jorge, V. (2005) o espaço-território é entendido como o espaço produzido e apropriado pela sociedade, composto pela inter-relação dos objetos naturais e culturais. O espaço é onde se sedimenta a memória humana, onde é mais densa a teia de significados decifráveis, fruindo uma relação com as pessoas que o habitam. Por outro lado, o espaço geográfico é o contínuo resultado das relações sócio espaciais. Tais relações podem ser económicas (relação sociedade-espaço mediatizada pelo trabalho), políticas (relação sociedade-Estado ou entre Estados-Nação) e simbólico-culturais (relação sociedade-espaço via linguagem e imaginário). A força motriz destas relações é a ação humana e as suas práticas espaciais (Lefébvre, 1991). Dentro deste espaçoterritório encontramos: Paisagem, lugar, território, região, sociedade e natureza.

A paisagem envolve elementos socioculturais resultante da formação histórica, cultural, emocional, físico, e da dinâmica natural. O lugar está relacionado com a dimensão cultural e fortemente relacionado com a identidade do espaço onde as relações de proximidade e afetividade dos indivíduos se entrelaçam. É onde as pessoas buscam referências pessoais (uma rua, um restaurante, um rio, uma estrada, uma casa, etc.) e constroem os seus sistemas de valores que fundamentam a vida em sociedade. Território deriva de terra, terra trabalhada e vivida, o que the dá desde logo certo estatuto de autenticidade, telúrico, ancorado. Há aqui implícito um sentimento de vivência e de pertença, cheio de simbolismos e de afectividades. $\mathrm{O}$ Território é também o resultado de um processo de divisão, histórica e geográfica, estando associado com limites e fronteiras. 0 território é temporário e modificável, depende das relações e escalas temporais. É onde ocorre as relações de poder e como os que o habitam o conhecem. As regiões são definidas pelas suas características, sejam elas políticoadministrativas, económicas, culturais, clima, vegetação, etc. Demangeon (1982) afirma que a Geografia Humana estuda a sociedade "relação dos grupos humanos com o meio geográfico", 
através dos modos de vida, a sua evolução, a sua distribuição e as instituições humanas. Moreira (1982) entende o espaço geográfico como estrutura de relações sob determinação do social. A natureza é um conjunto de elementos, dinâmicos e processos que se desenvolvem no tempo geológico.

Do ponto de vista político-administrativo, Boticas fica situada na Região (NUTS II) Norte, na Sub-região (NUTS III) Alto Trás-os-Montes e pertence à Comunidade Intermunicipal (CIM) do Alto Tâmega (engloba os Municípios de Boticas, Chaves, Montalegre, Ribeira de Pena, Valpaços e Vila Pouca de Aguiar). De acordo com Figura1, o concelho de Boticas, corresponde a uma parte da antiga terra do Barroso, pertencente ao distrito de Vila Real, tendo sido criada em 1836, no âmbito da reforma administrativa e da divisão territorial nacional desencadeada pela Segunda Revolução Liberal de 1832. O município é limitado a oeste e noroeste pelo município de Montalegre, a leste por Chaves, a sueste por Vila Pouca de Aguiar, a sul por Ribeira de Pena e a sudoeste por Cabeceiras de Basto. As freguesias de Boticas são as seguintes: Alturas do Barroso; Ardãos; Beça; Bobadela; Boticas; Cerdedo; Codessoso; Covas do Barroso; Curros; Dornelas; Fiães do Tâmega; Granja; Pinho; São Salvador de Viveiro; Sapiãos; Vilar.

Figura 1 - Localização do Concelho de Boticas

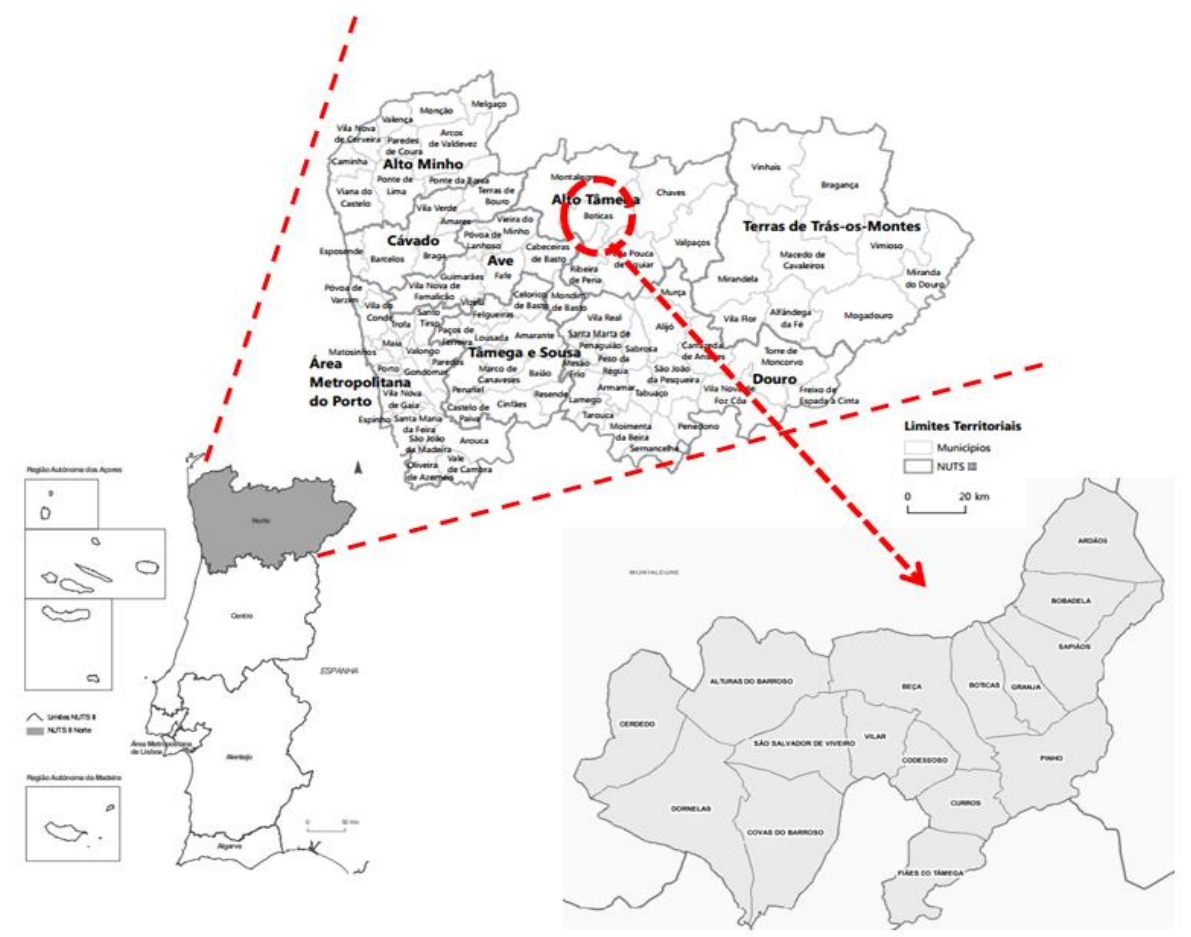

Fonte: Produção própria com base na Carta Administrativa Oficial de Portugal (CAOP), versão 2013.

Boticas assenta essencialmente numa vasta superfície planáltica, existindo vários tipos de paisagem, que vão desde a alta montanha granítica pobre em vegetação e rica em grandes penedias, passando pelos verdes vales cobertos por prados de lameiro. Oferece também áreas consideráveis de bosque onde as espécies dominantes autóctones são o carvalho roble e o carvalho negral nas zonas de maior altitude e o vidoeiro nas zonas de menor altitude, nas linhas 
de água é frequente o aparecimento do amieiro e salgueiro. É possível uma vasta e alargada visão para as serras de Cenábria, Larouco, Gerês, Cabreira e Marão, oferecendo assim uma rara imensidão de horizonte, por vezes entrecortado pelas águas da barragem do Alto Rabagão. Estas serras que cercam e dominam a região impuseram-lhe sérios condicionalismos de acessibilidade e comunicação, hoje ultrapassados. Na perspectiva demográfico, a região Norte (NUT II) possui 35\% (3 696762 habitantes) da população nacional (10.562.178), mas a sua distribuição pelas NUT III é desigual como se pode ver na Tabela 1.

Figura 2 - Nomenclatura Comum de Unidades Territoriais para fins Estatísticos (NUTS) estabelecida pelo regulamento comunitário no $868 / 2014$.

\begin{tabular}{|c|c|c|c|c|}
\hline NUTS I & NUTS II & NUTS III & $\begin{array}{l}\text { Populaçāo residente } \\
\text { (Censos 2011) }\end{array}$ & Municipios \\
\hline \multirow{23}{*}{ Continente } & \multirow{8}{*}{ Norte } & Alto Minho & 244836 & 10 \\
\hline & & Cávado & 410169 & 6 \\
\hline & & Ave & 425411 & 8 \\
\hline & & Área Metropolitana do Porto & 1759524 & 17 \\
\hline & & Alto Tàmega & 94143 & 6 \\
\hline & & Tămega e Sousa & 432915 & 11 \\
\hline & & Douro & 205157 & 19 \\
\hline & & Terras de Trás-os-Montes & 117527 & 9 \\
\hline & \multirow{8}{*}{ Centro } & Regižo de Aveiro & 370394 & 11 \\
\hline & & Regizo de Coimbra & 460139 & 19 \\
\hline & & Regiāo de Leiria & 294632 & 10 \\
\hline & & Viseu DJ̄o Lafōes & 267633 & 14 \\
\hline & & Beiras e Serra da Estrela & 236023 & 15 \\
\hline & & Beira Baixa & 89063 & 6 \\
\hline & & Oeste & 362540 & 12 \\
\hline & & Médio Tejo & 247331 & 13 \\
\hline & $\begin{array}{l}\text { Área Metropolitana de } \\
\text { Lisboa }\end{array}$ & Área Metropolitana de Lisboa & 2821876 & 18 \\
\hline & \multirow{5}{*}{ Alentejo } & Alentejo Litoral & 97925 & 5 \\
\hline & & Alto Alentejo & 118506 & 15 \\
\hline & & Alentejo Central & 166726 & 14 \\
\hline & & Baixo Alentejo & 126692 & 13 \\
\hline & & Leziria do Tejo & 247453 & 11 \\
\hline & Algarve & Algarve & 451006 & 16 \\
\hline
\end{tabular}

Fonte: INE, I. P. | Anuário Estatístico da Região Norte 2015 Statistical Yearbook of Norte Region 2015 | Statistics Portugal

As dinâmicas demográficas registadas nas últimas décadas em Portugal revelam que dois terços do território nacional, localizados em municípios do Interior do País (Territórios de Baixa Densidade), estão ameaçados de despovoamento e dos seus inevitáveis efeitos: a desertificação física provocada pelo abandono de terras e das atividades produtivas; o declínio das dinâmicas económicas e a perda de massa crítica - demográfica, social, económica e até institucional - necessária para viabilizar projetos e investimentos geradores da vitalidade necessária para manter níveis mínimos de ocupação do território; o acréscimo significativo 
dos custos de manutenção de infraestruturas e equipamentos de uso coletivo; a diminuição de serviços públicos fundamentais e a correspondente degradação da igualdade de oportunidades e de condições de vida.

De notar que o conceito de territórios de baixa densidade não está relacionado apenas com a dinâmica demográfica, envolvendo aspectos económicos e sociais, como a empregabilidade. Moutinho e Manso (2015) apelida este enqua-dramento de "inverno demográfico", onde os territórios de baixa densidade constituem mais de $80 \%$ do território continental, mas concentrando menos de $50 \%$ da população, 21\% da qual com 65 ou mais anos. Estes fatores contribuem para acentuar o decréscimo de serviços e equipamentos de proximidade fazendo diminuir as parcerias interterritoriais e enfraquecendo o envolvimento dos cidadãos. 0 reduzido desenvolvimento destes territórios de baixa densidade, com sistemas produtivos pouco mercantilizados e modernizados, torna-os dependentes de recursos externos (Silva \& Chamusca, 2010). Estão normalmente ligados a especialização em setores tradicionais, com dificuldades de modernização e, por conseguinte, pouco competitivos. A sua capacidade de reação aos fenómenos do envelhecimento e êxodo é diminuída (fatores que normalmente convivem nos territórios de baixa densidade). Num contexto territorial onde o tecido empresarial é frágil e incapaz de inverter o ciclo de regressão daí resultante, não raro é tirar pouco proveito das potencialidades relacionadas com os recursos naturais aí existentes (Silva, 2010). Nas últimas décadas temos assistido em Portugal a uma alteração na ocupação do território e na distribuição da população.

Tabela 2 - Repartição da população da NUT III

\begin{tabular}{lrc}
\hline NUT III & No Habitantes & (\% região norte) \\
\hline Alto Minho & 244836 & $7 \%$ \\
Cávado & 410169 & $11 \%$ \\
Ave & 425411 & $12 \%$ \\
Área Metropolitana do & & \\
Porto & 1759524 & $48 \%$ \\
Alto Tâmega (integra Boti- & & \\
cas) & 94143 & $\mathbf{3 \%}$ \\
Tâmega e Sousa & 432915 & $12 \%$ \\
Douro & 205157 & $6 \%$ \\
Terras de Trás-os-Montes & 117527 & $3 \%$ \\
$\quad$ Total região Norte & 3689682 & \\
\hline
\end{tabular}

Fonte: Produção própria com base no INE, 2012 - Censos Portugal 2011

A tabela 2 mostra que o Alto Tâmega possui 94143 habitantes (3\% da população do Norte de Portugal) integrando a Terra do Barroso, caracterizada como território de baixa densidade. Boticas é sede de um município com 321,96 $\mathrm{km}^{2}$ de área e 5750 habitantes (2011), sendo um território de baixa densidade populacional (Gráfi- $\cos 1$ ) e população envelhecida (Gráfico 2), mas com preciosos recursos endógenos como expressão cultural de matriz tradicional, alicerçado nas tradições e na memória coletiva regional, que podem ser valorizados pelo turismo, evitando assim o esquecimento. 
Gráfico 1 - Boticas - Evolução da população desde 1864 a 2011

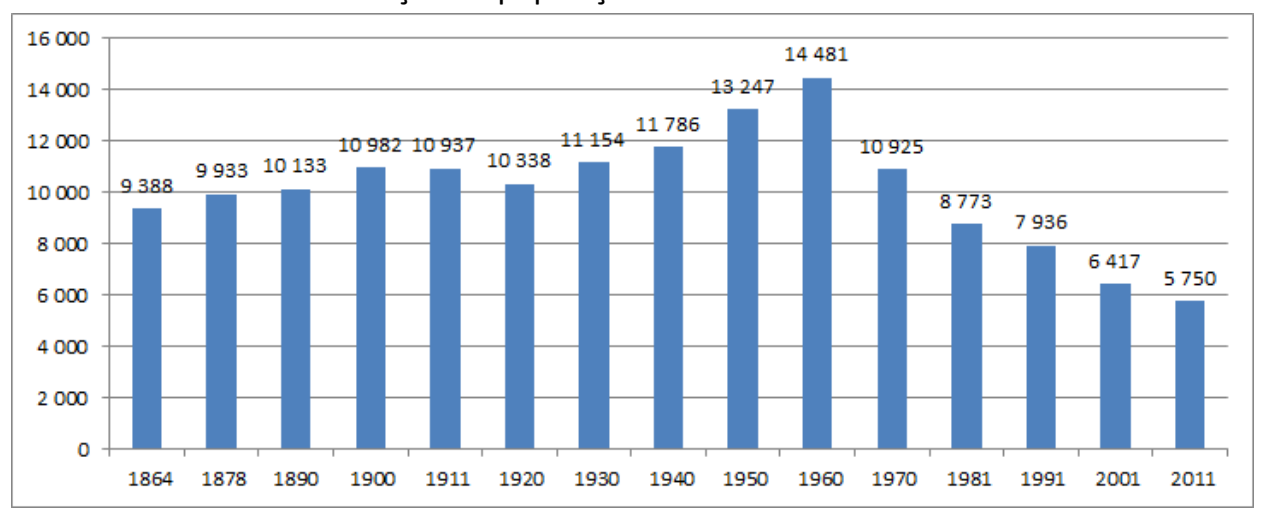

Fonte: Produção própria com base em dados INE (2012) - Censos de 2011- população total

Devido à sua localização geográfica e às difíceis acessibilidades, Boticas verifica um fenómeno da interioridade que tem vindo a contribuir para a baixa densidade populacional (Quadro 1), o baixo nível de produção e rendimento e o reduzido poder de compra. A informação supra é corroborada na Estratégia Integrada de Desenvolvimento Territorial do Alto Tâmega (p.24) "O Alto Tâmega tem enfrentado, nos últimos anos, um processo de diminuição progressiva e relativamente acentuada do número de residentes nos seus seis municípios: num período de dez anos, perdeu $11 \%$ da sua população. Com o aumento da esperança média de vida, a diminuição das taxas de natalidade $e$ uma consequente estrutura demográfica envelhecida, os índices de envelhecimento $e$ dependência de idosos são elevados, dificultando a renovação das gerações e o dinamismo da região".

Gráfico 2 - Boticas - Estrutura etária da população desde 1900 a 2011

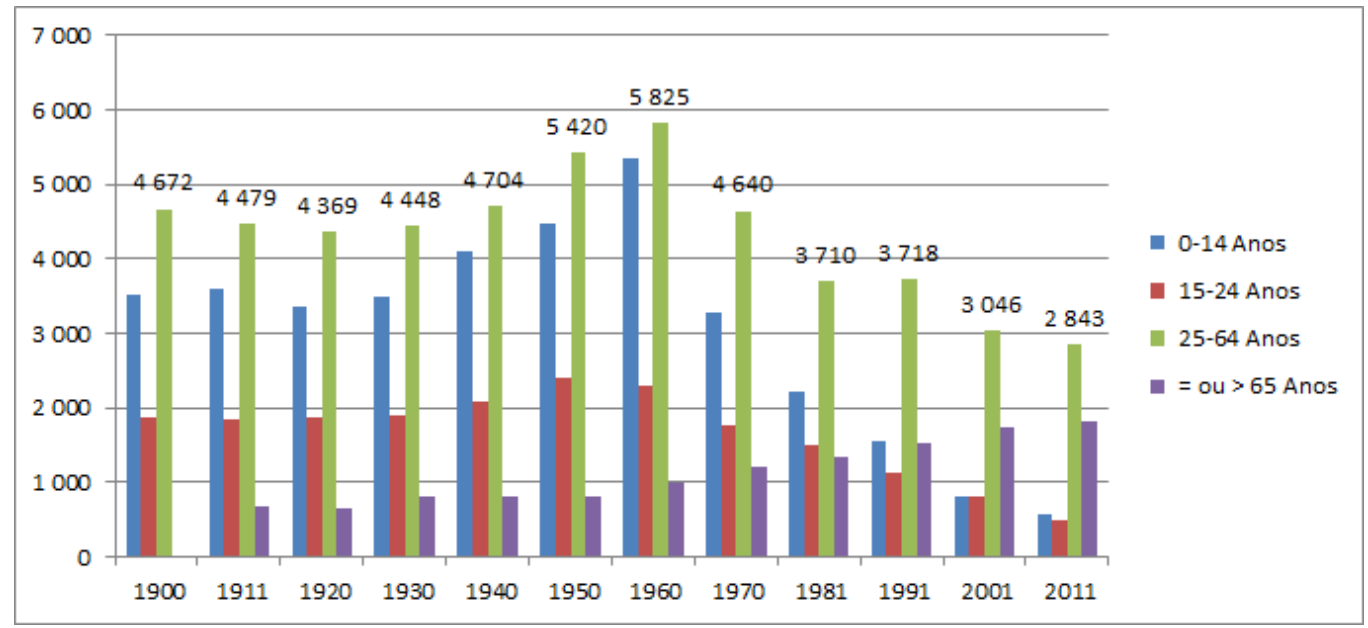

Fonte: Produção própria com base em dados INE (2012) - Censos de 2011- população total

O tratamento deste assunto deve ser visto como um motor potenciador de desenvolvimento e não um entrave à fixação de pessoas e ao desenvolvimento econômi-co. Em
Boticas verifica-se uma acentuada tendência do envelhecimento populacional (Gráfico 2) a par do agravamento do fenómeno de desertificação, a que não é alheia a parca acessibilidade a serviços 
públicos que contribui para o agravamento de situações de subdesenvolvimento, refletindo as difíceis condições de vida da população aí residente e suscitam a necessidade de encontrar diferentes formas de lidar com esta questão do ponto de vista das políticas públicas.

Por outro lado a Estratégia Integrada de Desenvolvimento Territorial do Alto Tâmega (p.26) refere que "A população do Alto Tâmega apresenta baixos níveis de formação $e$ qualificação quando comparada com a realidade nacional: mais de metade da população não tem escolaridade ou frequentou apenas o 10 Ciclo do Ensino Básico. Adicionalmente, salientam-se níveis de abandono escolar superiores à média nacional. Todavia, regista-se uma tendência positiva de melhoria da qualificação dos residentes ao longo dos últimos anos". Este cenário reflete a incapacidade da região em fixar recursos humanos qualificados.

\subsection{Vitivinicultura no território de Boticas}

O vinho é um dos produtos agrícolas que revelou uma mobilidade e capacidade de expansão mais elevadas ao longo da história, estando presente em todos os continentes. (Carlan, 2012 p. 85). A actividade lúdica associada ao vinho e à vinha não é um fenómeno recente. Os romanos começaram a interessar-se pelo vinho por volta de 200 a.C. e de entre as bebidas que os gregos consumiriam, o vinho assumia o primeiro lugar. Alguns romanos abastados possuíam casas de campo onde cultivavam vinhas e produziam pequenas quantidades de vinho para autoconsumo, ou para beber com os amigos que com eles vinham passar pequenas temporadas nestas quintas (Johnson's, 1989). A importância social, cultural e religiosa do acto de beber vinho é mais intensa no mundo grego do que no mundo romano (Montanari, 2008, p. 9192). Esta constituía uma forma de mostrar poder e impressionar os convidados, para além de que se constitui como uma primeira forma de prazer lúdico, associando uma viagem ao campo onde o vinho e a vinha já estão presentes.

O cultivo da vinha e a produção de vinho na Região de Trás-os-Montes tem origem secular existindo vários lagares cavados na rocha de origem Romana e Pré-Romana e vinhas velhas com castas centenárias marcando de uma forma muito peculiar a qualidade reconhecida dos vinhos desta região. Na região de Trás-os-Montes verifica-se a existência de vários microclimas, diversas tipologias de solos (graníticos com manchas de xisto) e a grande adaptabilidade das castas, possibilitando obter vinhos singulares. Tais diferenças permitiram definir três subregiões para a produção de vinhos de qualidade com direito a Denominação de Origem (DO) Trásos-Montes. As castas tintas mais importantes desta região são a Trincadeira, Bastardo, Marufo, Tinta Roriz, Touriga Nacional e Touriga Franca, e as castas brancas mais plantadas são a Síria, Fernão Pires, Gouveio, Malvasia Fina, Rabigato e Viosinho.

Os critérios tidos em conta foram essencialmente as altitudes, exposição solar, clima e a constituição dos solos, tendo sido a Denominação de Origem (DO Trás-os-Montes) reconhecida a partir de 9 de Novembro de 2006 (Portaria n.o 1204/2006), existindo 3 Sub-regiões, Chaves, Valpaços e Planalto Mirandês, assinaladas na Figura 3. 0 restante território que é considerada de Indicação Geográfica Protegida (IGP) transmontano, onde o Vinho dos Mortos é integrado. $O$ controlo e a defesa da Denominação de Origem e Indicação Geográfica, são da responsabilidade da entidade certificadora, a Comissão Vitivinícola Regional de Trás-osMontes (CVVTM) (criada em 1997) visando proteger e garantir a qualidade e genuinidade dos vinhos de qualidade produzidos naquela região. Tendo actualmente 94 produtores contribuindo com um volume anual de 3 milhões litros certificados. 
Figura 2 - Indicação Geográfica e Denominações de Origem - Região Vitivinícola de Trás-os-Montes

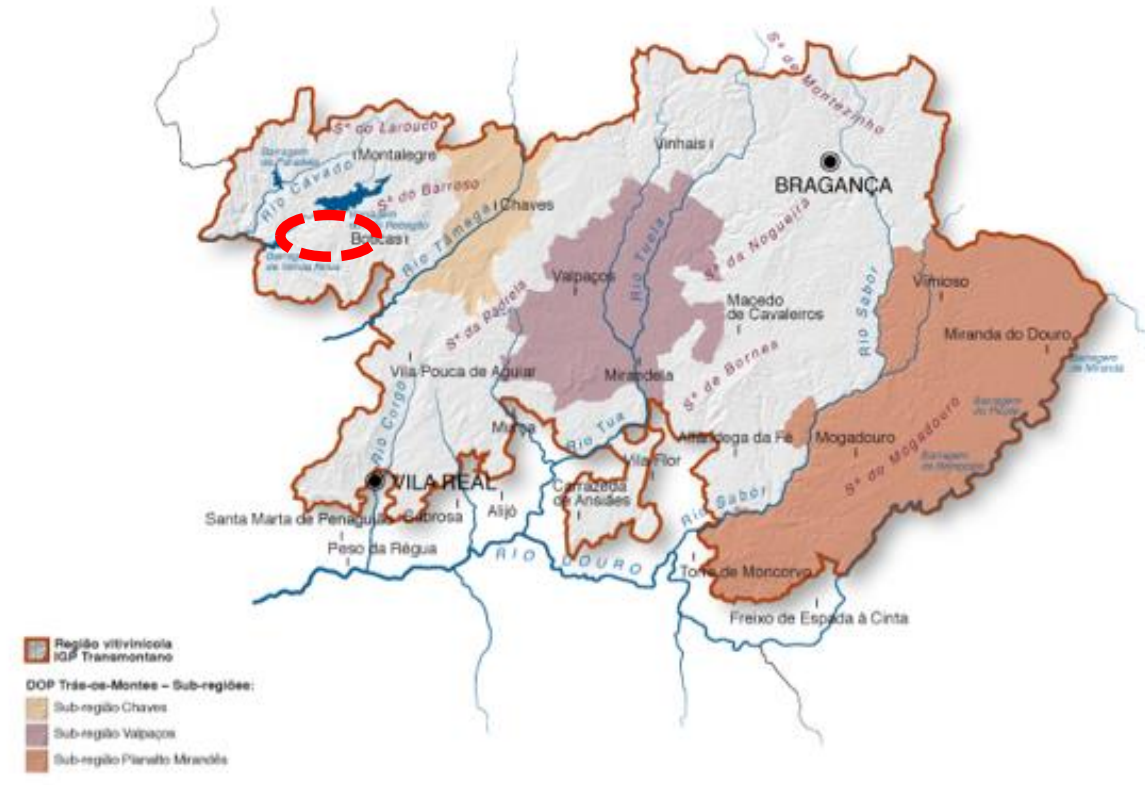

Fonte: anuário do IVV 2011 in http://www.vinetowinecircle.com/regioes/transmontano/

Explorando de forma sintética cada uma das sub-regiões de DO e segundo a informação da CVVTM a sub-região de Chaves está localizada na fronteira com Espanha para Norte, e famosa pelas suas águas termais, as vinhas situam-se nas encostas de pequenos vales, correndo em direção ao vale do Rio Tâmega. Nesta sub-Região, os solos são essencialmente graníticos com várias manchas de xisto, a altitude ronda os 350 a $400 \mathrm{~m}$ e verifica-se a incidência de valores elevados de pluviosidade e teores elevados de humidade relativa. Abrange os concelhos de Chaves (freguesias de Anelhe, Arcossó, Bustelo, Calvão, Cela, Curalha, Eiras, Ervededo, Faiões, Lama de Arcos, Loivos, Madalena, Oura, Outeiro Seco, Póvoa de Agrações, Redondelo, Samaiões, Sanjurge, Santa Cruz/Trindade, Santa Maria Maior, Santo António de Monforte, Santo Estêvão, São Pedro de Agostém, Seara Velha Selhariz, Soutelinho da Raia, Soutelo, Vale de Anta, Vidago, Vila Verde de Raia, Vilar de Nantes, Vilarelho da Raia, Vilarinho das Paranheiras, Vilas Boas, Vilela do Tâmega e Vilela Seca), Vila Pouca de Aguiar (freguesias de Capeludos e Valoura).
A sub-região de Valpaços localiza-se no centro do coração da Terra Quente Transmontana. Amplamente reconhecida pela produção de vinhos que remontam a tempos romanos, tal presença está intrinsecamente marcada nas rochas o maior número de lagares cavados na rocha até hoje identificados. Nesta Sub-Região, os solos apresentam diferenças significativas, ocorrendo uma maior incidência de manchas de xisto, existindo muitas zonas de transição com solos graníticos, a altitude ronda os 450 a $650 \mathrm{~m}$. No que se refere ao clima, verifica-se a ocorrência de temperaturas mais elevadas durante o verão e valores mais baixos de humidade relativa, bem como valores inferiores de pluviosidade. Abrange os concelhos de Macedo de Cavaleiros (freguesias de Arcas, Cortiços, Lamalonga, Sesulfe, e Vilarinho de Agrochão), Mirandela (freguesias de Abambres, Aguieiras, Alvites, Avantos, (excluindo as propriedades da Sociedade Clemente Meneres), Bouça, Cabanelas, Carvalhais (excluindo as propriedades da Sociedade Clemente Meneres), Fradizela, Franco, Lamas de Orelhão, Múrias, 
Mascarenhas, Mirandela, Passos, São Pedro Velho, São Salvador, Suçães, Torre de D. Chama, Vale de Gouvinhas, Vale de Salgueiro e Vale de Telhas), Murça (freguesia de Jou), Valpaços (freguesias de Água Revés e Castro, Ageriz, Barreiros, Bouçoães, Canaveses, Carrazedo de Montenegro, Ervões, Fornos do Pinhal, Possacos, Rio Torto, Sanfins, Santa Maria de Emeres, Santa Valha, São Pedro de Veiga de Lila, Sonim, Vales, Valpaços, Vassal, Veiga de Lila, e Vilarandelo), Vinhais (freguesias de Agrochão, Ervedosa, Rebordelo, Vale das Fontes, e Vale de Janeiro).

A sub-região do Planalto Mirandês está localizada no sudeste da Região de Trás-osMontes, na sub-região do Planalto Mirandês é o rio Douro que influência o cultivo da vinha. Nesta, os solos são essencialmente xistosos, a altitude ronda os 350 a $600 \mathrm{~m}$, verificando-se a ocorrência de grandes amplitudes térmicas e muito baixos teores de humidade relativa, bem como a incidência de ventos, tais características, associadas ao tradicional modo de condução da vinha em taça, ou cabeça de salgueiro, permitem um maior controlo da vinha, inibindo o desenvolvimento de certas doenças e permitindo desta forma uma viticultura praticamente biológica. Abrange os concelhos de Miranda do Douro, Mogadouro, Vimioso, Freixo de Espada à Cinta (freguesias de Fornos e Lagoaça), Torre de Moncorvo (freguesias de Carviçais, Felgar, Felgueiras, Larinho, Maçores, Mós e Souto da Velha, excluindo as áreas pertencentes à Região do Douro).

No que se refere aos vinhos com Identificação Geográfica Transmontano foi reconhecida a partir de 9 de Novembro de 2006 (Portaria n. 1203/2006). O "Vinho dos Mortos" incorpora-se nesta denominação, podendo ser produzidos em toda a Região. No sentido de divulgar este vinho, impulsionando desta forma a sua produção e venda, a Autarquia construiu em Granja, o Repositório do Vinho dos Mortos, para divulgação, observatório e preservação desse produto. A Cooperativa Agrícola de Boticas (CAPOLIB) é a detentora do registo da patente do "Vinho dos Mortos" e o Sr. Armindo Pereira, o único produtor "oficial" do mesmo.

\subsection{O Vinho dos Mortos, sua génese e outras práticas}

Entre 1807 e 1811 ocorreram três invasões a Portugal (Hobsbawn, E.,1977 e 1996; Silva, j., 2012), designadas por Invasões Francesas, tendo sido lideradas pelo general Junot e pelos Marechais Soult e Massena, respectivamente, conforme se observa na Figura 4. Com a primeira invasão francesa, em 1807, Junot (o comandante francês que liderou a 1a invasão) dirigiu-se para Alcântara, na fronteira com Portugal, entraram por Idanha-a-nova, Castelo Branco, Abrantes e seguiram até Lisboa. Não havia uma força portuguesa para se opor aos Franceses mas, pelo contrário havia uma representação diplomática com a intenção de fazer demorar o avanço para Lisboa e facilitar a fuga da família real. A família real foi viver para o Brasil para evitar dessa forma a perda da independência de Portugal. O país ficou sem monarca, que mudou a capital do reino para o Brasil, e todo o país ficou marcado pela morte, pilhagens e combates. As tropas napoleónicas deixaram no nosso país um rasto de destruição, mataram muitas pessoas, incendiaram casas, devastaram culturas. Junot dissolveu a Junta de Regência e passou a governar Portugal em nome de Napoleão.

De acordo com a História de Portugal de Oliveira Marques, "Quatro anos de guerra deixaram o país em situação miserável. As invasões e a ocupação francesas devastaram Portugal. A agricultura, a indústria e o comércio foram profundamente afetados, já para não falar nas perdas de vidas (...) e dos saques de mosteiros, palácios e até casas humildes." O comportamento dos soldados seguiam a máxima de Napoleão de que "a 
guerra deve sustentar a guerra" originando saques e roubos por parte das tropas e comandantes franceses, umas vezes para lucro pessoal e outras para a sobrevivência do exército.

A população portuguesa, muito desagradada com isto, reagiu contra o invasor, organizando em vários pontos do país, movimentos de resistência popular, mas foi precisa a ajuda de Inglaterra também. Em 1808 um exército inglês, liderado por Arthur Wellesley, desembarcou perto da Figueira da Foz e, juntando-se ao exército português, venceu os franceses nas Batalhas de Roliça e de Vimeiro, o que levou Junot a pedir a paz e a assinar a Convenção de Sintra, retirando-se de Portugal. Napoleão não desistiu de conquistar Portugal e então, ainda em Março de 1809 (no ano seguinte à retirada de Junot), o marechal Soult entrou em Portugal pelo Norte do país.

Figura 3 - Mapa das Invasões Francesas

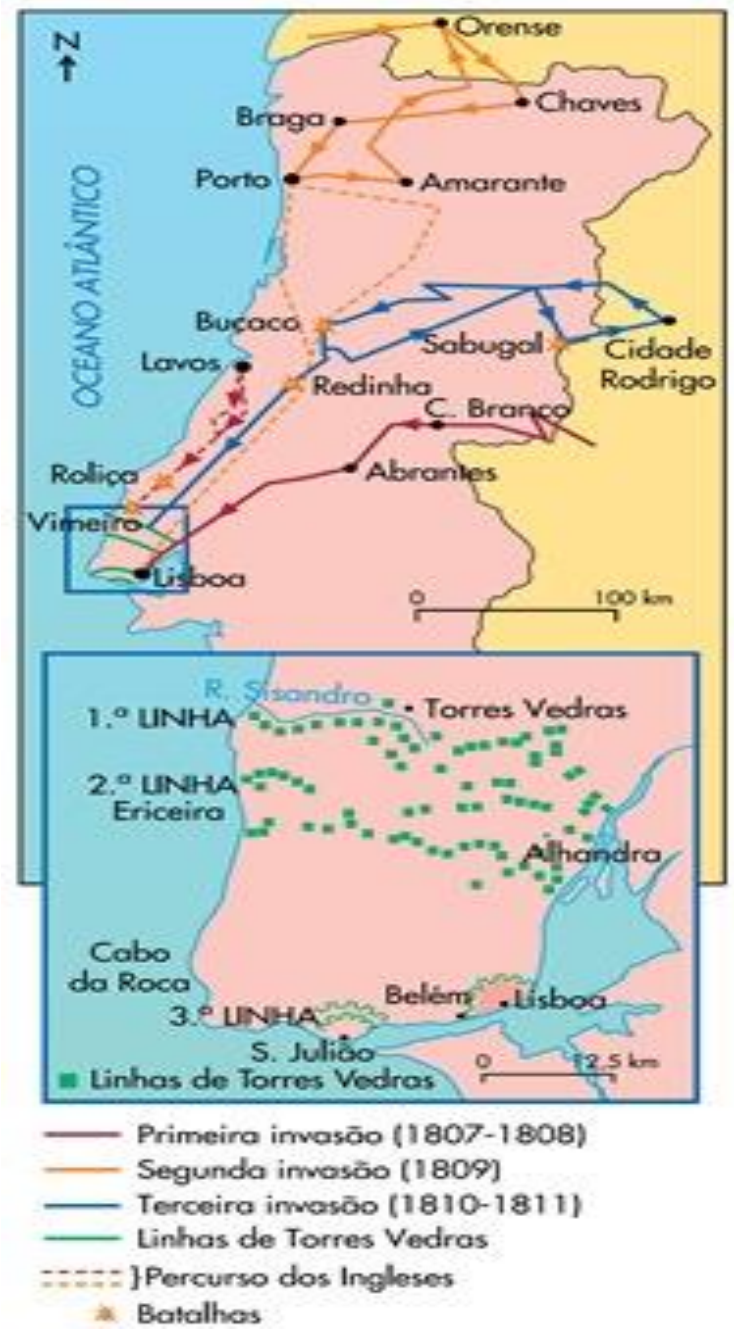

Fonte: Oliveira; Arinda Rodrigues; Cantanhede (2005)

As 2as invasões francesas entraram em Portugal por Chaves comandada pelo general Soult com destino à cidade do Porto. Da Fronteira de Chaves, continuaram a invasão, passando por
Sapiãos, Boticas, Couto Dornelas, prosseguindo os seus objectivos pelo caminho mais curto até ao Porto onde ocorreu o famoso desastre da ponte das barcas e o exército francês se afogou 
no Rio Douro. Foi durante a 2a Invasão Francesa (1808) e em face do avanço das tropas comandadas pelo General Soult que na sua passagem saqueavam pilhavam e destruíam, que a população de Boticas, para tentar defender o seu patrimônio, decidiu esconder, enterrando, o que tinha de mais valioso. Os soldados, pelo caminho, tiveram o comportamento dos da primeira invasão até Lisboa: por onde passavam, pilhavam tudo o que mais Ihes agradava, mesmo para se alimentarem. Aqui nascem as Lendas de São Sebastião e a do Vinho dos Mortos de Boticas. A lenda do Vinho dos Mortos diz-se que os lavradores de Boticas, para não serem roubados pelos soldados durante as Invasões francesas, enterraram as vasilhas (garrafas) do vinho, deitando-as ao comprido e cobrindo-as com terra como se faz aos mortos nos cemitérios. $O$ vinho foi en-

terrado no chão das adegas, no saibro, debaixo das pipas e dos lagares. E os militares tiveram de se contentar com a água das fontes.

Portanto foram as 2as Invasões Francesas que vieram originar o aparecimento do que hoje é um verdadeiro ex-libris de Boticas - o Vinho dos Mortos. Assim este vinho, por ter sido "enterrado" ficou a designar-se por "Vinho dos Mortos" e passou a utilizar-se esta técnica para melhor o conservar e optimizar a sua qualidade. O Vinho dos Mortos é, por isso, o símbolo de uma guerra de subsistência, não só material e económica, mas também e essencialmente moral. É o exemplo da sagacidade e da resistência do povo de Boticas, obrigado a usar das mais inimagináveis formas de preservar o seu património.

A 3a invasão francesa aconteceu em JuIho de 1810, o general Massena e o seu exército, entrou em Portugal por Almeida, na Beira Alta e dirigiram-se para Lisboa onde foram derrotados na Batalha do Buçaco. Continuaram, contudo a avançar em direç̧ão à capital, mas foram detidos nas Linhas de Torres, que eram constituídas por um conjunto de fortificações que os ingleses nos tinham ajudado a construir. Vencidos, os france- ses foram obrigados a retirar-se definitivamente de Portugal, em Março de 1811. Após a expulsão dos franceses, os habitantes recuperaram as suas casas e os bens que restaram. Em Boticas, ao desenterrarem o "vinho dos mortos" julgaram-no estragado. Porém, descobriram com agrado que estava muito mais saboroso, pois tinha adquirido propriedades novas. Era um vinho com uma graduação de 10\%/11으, palhete, apaladado, e com algum gás natural, que lhe adveio da circunstância de se ter produzido uma fermentação no escuro a temperatura constante.

Em pleno século XXI a lenda, a tradição e o processo de conservação do "Vinho dos Mortos" é perpetuado com orgulho e transmitido este património imaterial da vila de Boticas pelo mundo, através do único produtor. O Sr. Armindo Sousa Pereira, de Boticas, no distrito de Vila Real, é o único produtor e engarrafador registado oficialmente para comercializar o "Vinho dos Mortos" estando no mercado há 9 anos. $O$ viticultor transformou em negócio o saber que herdou dos avós e dos pais, dos quais se recorda sempre terem vendido "Vinho dos Mortos" num pequeno comércio que tinham no centro da vila. A sua coIheita de 2013 foi de 6.500 garrafas que, foram vendidas de norte a sul do país e levadas "alémfronteiras" pelos emigrantes e turistas que passam pela vila de Trás-os-Montes. De acordo com o Diário de Notícias de 14 de Outubro de 2013, refere que "Ao não vender para o exterior, o meu objetivo é atrair até Boticas os curiosos e, assim, impulsionar a economia local". As encomendas, disse o viticultor, poderão ser feitas nu sítio da Internet (www.vinhodosmortos.com) e chegam ao destino em 24 horas, mas também estão disponíveis no posto de turismo, restaurantes, lojas e no repositório do "Vinho dos Mortos", em Boticas, edifício construído pela câmara para preservar esta tradição.

Esta tradição do "Vinho dos Mortos" foi replicada no Brasil, na adega Quinta do Olivardo, em São Roque (SP), conforme relata o Sorocaba 
e Jundiaí em 21/05/2016

(http://g1.globo.com/sao-paulo/sorocaba-jundiai/noticia/2016/05/tradicao-do-vinho-dosmortos-e-atracao-deste-sabado-em-sao-roque.html) e pelo jornal Sabores de 24-05-2016.

\section{4 "Vinho de Água" outra prática de vinho enterrado}

Outra prática de vinhos enterrados surge a inovadora, ideia recente de um produtor de vinhos no Alentejo, que no fundo do Alqueva fez repousar 30 mil garrafas do seu topo de gama, o Conde D'Ervideira Reserva Tinto 2014 (uma mistura produzida a partir da seleções melhores lotes das castas Touriga Nacional, Aragonez, Tinta Caiada, Alicante Bouschet e Cabernet Sauvignon, vinificadas casta-a-casta), nas águas do Alqueva, nas imediações da Amieira Marina, no concelho de Portel, Évora, sendo rotuladas como o Vinho de Água. O projeto é recuperar uma história antiga, em que barcos que se afundavam com vinhos revelaram, depois, ter vinhos extraordinários.

A técnica de submergir garrafas é antiga, da época dos Descobrimentos, quando os barcos e naus em que eram transportados naufragavam e os vinhos ficavam submersos até serem encontrados. Conforme referido pela Agência Lusa em 20-10-2015, as garrafas seladas, lacradas e acondicionadas dentro de caixas de grande dimensão, foram colocadas dentro de água, com a ajuda de um trator e de um barco, indo estagiar nas profundezas da albufeira (15 ou 17 metros), a 17 graus e até aos 30 metros, no máximo. 0 vinho, que já estagiou oito meses em barrica, foi submetido a este novo estágio dentro de água, no mínimo durante oito meses tendo sido baptizado como "Vinho da Água". Segundo a mesma notícia este processo "Dá vinhos de um nível extraordinário (...)" e "maturação muito nobre, exuberante e redonda em termos de taninos".

De acordo com notícia em
WWW.Dinheirovivo.pt/topico/vinhos/ de 27-022016 "Produtor vitivinícola do Alentejo, registou um aumento de $20 \%$ nas vendas, face a 2014 , dos vinhos topo de gama. Agora aposta no Vinho de Água". Esta aposta na diferença originou a venda de 600 mil garrafas durante o ano de 2015, representando um aumento de $20 \%$ quando comparado com igual período de 2014 .

\section{ECOSSISTEMA DO TURISMO DE VINHO}

Juntando a indústria do "vinho dos mortos" ao turismo e ao forte carácter identitário do território de Boticas, é possível a criação de uma visão sistémica de oportunidades de desenvolvimento socioeconómico e de fixação de população, através de maiores oportunidades de trabalho e aumento (e melhoria) dos serviços prestados, assim como o incremento de infraestruturas. O turismo poderá ser um excelente veículo de resgate da memória e de construção de uma identidade cultural, garantindo a continuidade das tradições ao longo das gerações, resultante do processo de socialização que the é inerente, onde o indivíduo aprende e interioriza o sistema de valores, de normas e comportamentos de uma determinada cultura. Matos (2013) sugere a criação de redes de proximidade, através da capacitação dos agentes locais, da formulação de políticas públicas com uma base estratégica forte, devendo ser a base de sustentação da maximização dos serviços e competências existentes e pressupor a criação de novos serviços.

A reunião de todos estes elementos enquadra-se no conceito de ecossistema quando combina os interesses de todos os stakeholders. Transpondo este conceito - ecossistema, para o turismo de vinho, surge o ecossistema de enoturismo, colocando o foco no modelo de desenvolvimento dos territórios, privilegiando o relacionamento win-win entre stakeholders, (estratégias de colaboração) na geração de valor, 
e promovendo uma maior conectividade e cooperação entre players e regiões.

A Carta Europeia do enoturismo (2006, p.2) define o conceito como o desenvolvimento de todas as actividades turísticas e de lazer dedicadas à descoberta e ao conhecimento cultural vitivinícola. Um dos factores críticos de sucesso do ecossistema é a implementação de estratégias de cooperação. Howley \& Westering, (2008), bem como Hall et al (2000) abordam os benefícios da cooperação, somando ao debate as vantagens das redes comerciais, com evidentes benefícios para os territórios de rotas do vinho e para os negócios dos produtores. Na mesma linha de pensamento de Hall et al (2000), Inácio (2008) e Costa (2007) propõem uma contribuição holística, mostrando a importante associação do Enoturismo com rotas vitivinícolas e com o património cultural. Nos tempos recentes, temse assistido à integração do Turismo (setor terciário) com os outros sectores (primário e secundário), introduzindo uma união privilegiada no ecossistema do Enoturismo (turismo, território e cultura do vinho), agregando um vasto conjunto de atividades culturais, experiências turísticas de origem material, imaterial e de sociabilidade ligado à cultura do vinho.

De acordo com Salvado (2016, p.84) o ecossistema do Enoturismo considera três pilares visando o desenvolvimento dos territórios: Território/Paisagem/Património, Cultura do Vinho, e Turismo, sustentados por Políticas focadas nos recursos endógenos.

\subsection{Território/Paisagem/Património}

O Território é a base material para a paisagem. O conceito de "paisagem" tem um significado múltiplo e é intrinsecamente holístico: paisagem como território, como percepção, como património, como recurso. A Convenção Europeia sobre a Paisagem, aprovada pelo Conselho da Europa em Julho de 2000, define o conceito de Paisagem como "... um componente básico do património natural e cultural europeu"; "Uma área percebida por pessoas cujo carácter é o resultado da ação e da interação de fatores naturais e / ou humanos".

Consequentemente, Território, Paisagem e Património tornam-se conceitos inseparáveis que permitem a utilização simultânea de todos os componentes físicos, biológicos e culturais que compõem o espaço-território. Pode-se então considerar que a paisagem é uma pegada da sociedade sobre a natureza e paisagens anteriores, tornando-se também a consciência social e a consciência do território pelas pessoas que vivem lá. Os territórios vitivinícolas rurais estão a ser vendidos como um paraíso rural onde o lazer, a cozinha, a sociabilidade entre anfitrião e visitante, o cenário e as actividades ao ar livre proporcionam experiências turísticas únicas, com ênfase nos estilos de vida e na paisagem rural. De acordo com Kastenholz, [et al.] (2014), no estudo ORTE, o potencial da experiência turística em espaços rurais está dependente, em larga medida, dos contextos e dos recursos (materiais e imateriais) existentes nesses territórios. Simultaneamente há uma necessidade percebida de reter ou atrair pessoas em muitas áreas rurais, especialmente as que testemunham o êxodo rural devido ao declínio do papel da agricultura, para manter aspetos do estilo de vida rural tradicional e produção agrícola e conservar a paisagem rural (Eusébio, Kastenholz \& Breda, 2016).

O turismo ligado ao vinho é um factor significativo no desenvolvimento rural, através da criação de postos de trabalho, da venda de produtos locais, da melhoria das infra-estruturas turísticas regionais e da promoção de investimentos em múltiplos domínios. A paisagem holística do Enoturismo é importante, pois é um pilar de autenticidade cultural valioso, que se estende a todo o território, e tem um potencial enorme de criação de experiências turísticas singulares. 


\subsection{A Cultura do Vinho:}

A vinha e o vinho fazem parte de um património cultural ligado à história e tem sido um elemento essencial para o desenvolvimento económico, social e cultural das diferentes regiões vitícolas. A cultura do vinho tem crescido como parte da vida, da cultura, da sociabilidade e dieta desde tempos imemoriais. Como símbolo cultural, a importância do vinho mudou ao longo do tempo, passando de uma fonte imperativa de nutrição para um complemento cultural para alimentos e convivência, compatível com um estilo de vida saudável.

Promover a Cultura do Vinho significa difundir autenticidade para as origens, e um produto fortemente ligado à gastronomia, aos prazeres do gosto e ao património cultural do território. De acordo com Deloitte European Enotourism Handbook - Projeto Vintur (2005, p.4) "Sem a cultura do vinho, o Enoturismo não existe. $\mathrm{O}$ valor enológico-cultural determina o peso do elemento do vinho como um eixo ou uma vértebra da experiência turística". Como referem Santos \& Cunha (2008), a forte associação de produtos locais ao território, como se verifica no caso dos vinhos e das Regiões Demarcadas, servem de referência à qualidade de produtos que pretendem ser identitários em relação aos territórios onde são produzidos, pela capacidade de promover a integração de produtos turísticos diversos em torno de propostas de grande pertinência para o desenvolvimento local sustentável.

\subsection{O Turismo}

Goeldner \& Ritchie (2006) argumentam que o ecossistema do turismo consiste em redes de organizações que se estendem por várias escalas / indústrias / atividades espaciais diferentes, conectando vários tipos de atores relacionando diferentes valores, papéis, interesses, capacidades, práticas e diversidade de recursos e ideias. Mas que factores podem afetar uma experiencia memorável? Nesta perspectiva Williams (2001, p.9) considera o turismo do vinho como "o culminar de uma série de experiências únicas, como o ambiente, atmosfera, paisagem, cultura e gastronomia regionais, estilos e variedades de vinhos locais".

O grande desafio para os gestores é criar experiências únicas a fim de obter visitantes leais (Cole \& Chancellor, 2009, Saayman \& van der Merwe, 2014). Se o turismo é "experiência", Urry (1999) e Cooper \& Hall (2008) consideram o turismo do vinho como uma "experiência total", por incluir um conjunto de Recursos endógenos (tangíveis e intangíveis), atracções regionais, equipamentos e infra-estruturas de apoio, actividades de entretenimento, imagens simbólicas locais e valores. Na investigação de Kastenholz [et al.] (2014, p. 15) os contextos de experiências ("experience settings") deverão ser adaptados aos heterogéneos desejos dos clientes/mercados. Kastenholz [et al.] (2014, p. 114) considera que a actividade de Enoturismo tem contribuído para o desenvolvimento e manutenção de actividades económicas tradicionais e beneficiando os produtores locais e regionais.

Segundo a TP (2015, p.27), o turismo de vinho é uma actividade muito jovem em Portugal, revelando que $51 \%$ dos empresários iniciaram as suas actividades em 2000 (década) e 27\% iniciaram a sua actividade em 2010-2013. O Enoturismo é também uma actividade complementar à produção de vinho, uma vez que $50 \%$ dos empreendedores são produtores de vinho, $14 \%$ exploram a viticultura e $7 \%$ Turismo no espaço rural. Na perspectiva da Procura, e segundo a TP $(2015$, p.27) $24 \%$ dos turistas têm o Enoturismo como principal motivação de viagem, vivenciando uma experiencia turística diversificada, ao incluir: i) degustação de vinhos; ii) compra de vinho; iii) visita a adegas e vinhas; 
iv) aprender sobre a paisagem local, comunidades e donos de vinícolas; v) descobrir o património cultural; vi) e compreender a paisagem da região e um expressivo agente motivador para o desenvolvimento dos negócios e dos territórios.

\subsection{Políticas}

Para garantir o sucesso dos três pilares enunciados, o ecossistema de Enoturismo deve sustentar-se em políticas. Chuck (1997) define Política como um plano geral de alto nível que inclui metas e procedimentos, geralmente encontrados em declarações formais, como leis e documentos e declarações oficiais. Em Portugal esteve em vigor até 2015 o PENT [Plano Nacional de Turismo Estratégico (TP 2013, p.18)] que deu ênfase às indústrias do vinho e do turismo alertando para a necessidade de criar uma diversificada experiência de identidade e experiência regional.

É crucial acomodar as políticas nacio-nais e europeias de Enoturismo com as polí-ticas ligadas ao património, como a Conven-ção Europeia da Paisagem (Decreto n. 4/2005 Convenção Europeia da Paisagem, feita em Florença em 20 de Outubro de 2000). Para a ELC, todos os stakeholders no território de Enoturismo devem atingir os seguintes objetivos: i) reconhecer as paisagens como componentes essenciais do ambiente das pessoas, expressão da diversidade do seu património cultural e natural e a base da sua identidade; ii) estabelecer procedimentos para a participação do público em geral, das autarquias locais e regionais e de outras partes interessadas na definição e execução das políticas de paisagem; iii) integrar a paisagem nas suas políticas regionais e de urbanismo e nas suas políticas culturais, ambientais, agrícolas, sociais e económicas, bem como em quaisquer outras políticas com possível impacto directo ou indirecto na paisagem.
Portanto, o desenvolvimento terri-torial só é possível se se tiver em conta as especificidades e os atributos únicos de cada território - sejam culturais, ambientais, paisagísticas, infra-estruturais ou demo-gráficas. Segundo Kuper (1999), as diferentes culturas são convenções transmitidas social-mente, dinâmicas e mutáveis, e refletem conjuntos de ideias e valores. De acordo com Brunet (1990), no espaço-território as relações sociais entre os atores locais, fazem surgir um sentimento de pertença à identi-dade construída, criando laços de solidarie-dade entre eles. Sabourin (2002) corrobora a ideia, de que a valorização conjunta e negociada do potencial das localidades, das coletividades ou das regiões, são chamadas de atributos locais ou de ativos específicos. Jollivet, (1984) considera ainda que uma região tem o poder de se manifestar permanentemente a partir da memória coletiva e das relações sociais que são formadas pelas interações locais e externas.

Mas a presença da cultura local permanece importante na formação da identidade do território, dando-lhe contornos específicos, sendo um atributo singular quando a integramos no sector do turismo. O turismo é hoje a mais importante atividade de serviços à escala global com uma forte dimensão cultural. Constata-se que o desejo de viajar, de conhecer novos povos e novas culturas gerou uma interação entre as culturais externas com as culturas locais cujo resultado se diferencia entre os diferentes territórios (podendo gerar aculturação). Isto implica que as políticas devem ser pensadas de forma integrada, levando em consideração as necessidades e potencialidades de cada território (Matos, 2013).

Em Portugal o Governo estabeleceu no seu programa a necessidade de adoptar uma Política Nacional de Turismo (PENT), capaz de integrar de forma coerente diversidades e diferenças 
locais, através de «políticas regionais fortes». Importa que o diagnóstico em turismo considere as políticas e linhas estratégicas definidas pelas organizações internacionais ligadas ao setor, nomeadamente a Organização Mundial do Turismo e a Comissão Europeia (área do turismo), a nível nacional, pela Secretaria de Estado do Turismo e o Turismo de Portugal, a nível regional e local pela Comissão de Coordenação e Desenvolvimento Regional do Norte (CCDR Norte) e as linhas definidas pela Câmara Municipal de Boticas. A Região de Boticas apresenta grande diversidade territorial integrando diferentes paisagens naturais e culturais com potencial para utilizações turísticas distintas.

\section{METODOLOGIA DE INVESTIGAÇÃO}

O processo de investigação para além de ser uma forma de aplicar conhecimentos é também um processo de planificação e de criatividade controlada (Hill e Hill 2000), considerando a dualidade de aspectos: contributo para o planeamento da investigação e o enriquecimento do conhecimento. Este trabalho considerou uma relevante análise da bibliografia sobre o espaço geográfico e cultural de Boticas. Após construção do referencial teórico de suporte à temática, onde se procuraram bases conceptuais organizadas e sistematizadas do conhecimento disponível acerca da caracterização do território em estudo e dos conceitos ligados ao ecossistema do turismo de vinhos, foi realizado um levantamento bibliográfico consultando livros e revistas especializadas para perceber o que já teria sido estudado nesta vertente de investigação.

Os dois eixos metodológicos de cariz qualitativo utilizados abarcaram a MatrizPCI (Matriz Património Cultural Imaterial) para inventariação dos recursos das Terras de Barroso e o Modelo dos 6 A's de Buhalis (2003)
[1.Atrações (naturais ou artificiais), 2.Acessibilidades (Sistema de transportes), 3.Amenidades oferta retalhista e outros serviços turísticos), 4.Alojamento, 5.Available Packages pacotes Turísticos e 6.Auxiliares - Serviços auxiliares (bancos, telecomunicações, etc...)] que permite elencar os recursos endógenos do território e descobrir os drivers de desenvolvimento sustentável.

\subsection{Matriz PCl (Património Cultural Imaterial)}

O principal esforço para a valorização e a salvaguarda do Património Material e Imaterial tem sido realizado pela UNESCO (Organização das Nações Unidas para a Educação, Ciência e Cultura) que, em 2003, elaborou a "Convenção para a Salvaguarda de Património Cultural Imaterial". Portugal, através da Direcção-Geral do Património Cultural, seguiu essa política, desenvolvendo um Kit de Recolha de dados de Património, que foi utilizado nesta investigação. No tocante ao "Vinho dos Mortos" de Boticas, entendemos que o acervo histórico/cultural (material e imaterial) deste território deve ser devidamente documentado, utilizando a MatrizPCI (Matriz Património Cultural Imaterial), pois as comunidades locais (as freguesias do Concelho de Boticas que recuperaram este símbolo identitário) reconhecem-no como símbolo de afinidade do seu património cultural, transmitindo este orgulho entre gerações.

O preenchimento da Ficha de Património Imaterial: Vinho dos Mortos de Boticas [Modelo Fonte: MatrizPCI (2006) - Matriz Património Cultural Imaterial] utilizou a observação como técnica de investigação interpretativa; teve o território como fonte direta dos dados; decorreu de um trabalho intensivo de campo, onde as questões foram estudadas sem qualquer manipulação intencional do pesquisador. A recolha de dados primários assentou em: 1. Observação do património (visita a Boticas), 
tendo sido considerados os seguintes aspetos: espaciais (Território: Concelho de Boticas); temporais (observação realizada entre Agosto 2016 a Março de 2017); observação (Património material e Imaterial e recursos endógenos principais do concelho de Boticas); condução da observação (preenchimento de grelha de inventariação património imaterial e observação in loco de recursos). 2. Pesquisa documental (consulta de bibliotecas, artigos de jornal, livros). Após esta recolha de informação foi possível preencher a Matriz PCI (Quadro 1).

Quadro 1 - Ficha de Património Imaterial: Vinho dos Mortos de Boticas

(continua)

\begin{tabular}{|c|c|}
\hline Domínio: & Práticas sociais, saberes e processos \\
\hline Categoria: & Prática de vinificação \\
\hline Denominação: & Vinho dos Mortos de Boticas \\
\hline Contexto social: & $\begin{array}{l}\text { A lenda, a tradição e o processo de conservação do "Vinho dos Mortos" é perpetuado com } \\
\text { orgulho e transmitido este património imaterial da vila de Boticas pelo mundo, através do } \\
\text { único produtor. }\end{array}$ \\
\hline $\begin{array}{l}\text { Contexto territo- } \\
\text { rial: }\end{array}$ & $\begin{array}{l}\text { O concelho de Boticas está situado na parte noroeste de Portugal, província de Trás-os- } \\
\text { Montes, Distrito de Vila Real. Criado no âmbito da reforma administrativa de 1836, o actual } \\
\text { concelho de Boticas corresponde a uma parte da antiga terra do Barroso. }\end{array}$ \\
\hline Contexto temporal: & Agosto 2016 a Março de 2017 \\
\hline $\begin{array}{l}\text { Caracterização sín- } \\
\text { tese: }\end{array}$ & Processo de vinificação/sistema de envelhecimento vínico \\
\hline $\begin{array}{l}\text { Caracterização } \\
\text { desenvolvida: }\end{array}$ & Garrafas de vinho enterradas: tradição desde o século XIX \\
\hline $\begin{array}{l}\text { Contexto transmis- } \\
\text { são: }\end{array}$ & $\begin{array}{l}\text { Estado de transmissão: ativo } \\
\text { Descrição: prática } \\
\text { Modo de aprendizagem das gerações mais novas: A participação } \\
\text { Modo de transmissão: oral, escrita, prática do processo } \\
\text { Idioma(s): português; } \\
\text { Agente(s) de transmissão: Câmara Municipal de Boticas; Comissão Vitivinícola Regional de } \\
\text { Trás-os-Montes. }\end{array}$ \\
\hline Origem / Historial: & $\begin{array}{l}\text { Foram as Invasões Francesas que vieram originar o aparecimento do que hoje é um verda- } \\
\text { deiro ex-libris de Boticas - O VINHO DOS MORTOS. Foi durante a } 2 \text { a Invasão Francesa } \\
\text { (1808) e em face do avanço das tropas comandadas pelo General Soult, que na sua passa- } \\
\text { gem tudo saqueava, pilhavam e destruíam, que a população de Boticas, para tentar defen- } \\
\text { der o seu património, decidiu esconder, enterrando, o que tinha de mais valioso. O vinho } \\
\text { foi enterrado no chão das adegas, no saibro, debaixo das pipas e dos lagares. Mais tarde, } \\
\text { depois dos franceses terem sido expulsos, os habitantes recuperaram as suas casas e os } \\
\text { bens que restaram. Ao desenterrarem o vinho, julgaram-no estragado. Porém, descobri- } \\
\text { ram com agrado que estava muito mais saboroso, pois tinha adquirido propriedades novas. } \\
\text { Era um vinho com uma graduação de } 10 \text { o/11o, palhete, apaladado, e com algum gás natu- } \\
\text { ral, que lhe adveio da circunstância de se ter produzido uma fermentação no escuro a tem- } \\
\text { peratura constante. }\end{array}$ \\
\hline
\end{tabular}


Quadro 1 - Ficha de Património Imaterial: Vinho dos Mortos de Boticas

(conclusão)

\begin{tabular}{|c|c|}
\hline $\begin{array}{l}\text { Fundamentação do } \\
\text { Processo: }\end{array}$ & $\begin{array}{l}\text { Critérios genéricos de apreciação: } \\
\text { Património Associado: } \\
\text { Património cultural imaterial: O processo de envelhecimento/conservação do vinho } \\
\text { Estudos, metodologias e programas: Estão a ser desenvolvidos estudos acerca da existên- } \\
\text { cia, características do processo em cada freguesia do Concelho de Boticas, usando a meto- } \\
\text { dologia MatrizPCI. } \\
\text { Riscos e ameaças: No sentido da valorização das expressões culturais de matriz tradicional } \\
\text { e a afirmação social e projeção da voz das comunidades, grupos e indivíduos que se cons- } \\
\text { tituem como detentores deste património, evitando o esquecimento, serão propostas a } \\
\text { realização de workshops/recriações históricas envolvendo temáticas das Invasões france- } \\
\text { sas e inventário e valorização do Património Cultural material e Imaterial em Boticas. Será } \\
\text { crucial facultar formação especializada na área da inventariação e salvaguarda do Patri- } \\
\text { mónio Cultural Imaterial (PCl), desenvolvendo competências específicas para a instrução } \\
\text { dos procedimentos de proteção legal com vista ao registo deste tipo de expressões cultu- } \\
\text { rais no Inventário Nacional do Património Cultural Imaterial (INPCI). Para tal, importa fa- } \\
\text { cultar competências quanto aos métodos e às técnicas de investigação etnográfica, e pro- } \\
\text { mover o envolvimento e participação ativa dos detentores do PCl no processo da sua pa- } \\
\text { trimonialização e salvaguarda. } \\
\text { Ações de salvaguarda: As salvaguardas são medidas que buscam garantir a viabilidade e a } \\
\text { sustentabilidade cultural do património cultural imaterial, no concelho de Boticas. Importa } \\
\text { a sua identificação, a documentação, a investigação, a preservação, a proteção, a promo- } \\
\text { ção, a valorização, a transmissão e a revitalização deste património (vinho dos mortos) nos } \\
\text { seus diversos aspetos. Com o objetivo da salvaguarda e valorização deste Património Ima- } \\
\text { terial, serão propostas ações de boas práticas que incluam: mapeamento e pesquisa dos } \\
\text { locais onde ainda se pratica este processo, produção bibliográfica e audiovisual de materi- } \\
\text { ais acerca do vinho dos mortos, ações educativas, formação, ações de formação, transmis- } \\
\text { são de saberes, apoio à organização e à mobilização comunitária e promoção da utilização } \\
\text { sustentável dos recursos naturais }\end{array}$ \\
\hline Bibliografia & $\begin{array}{l}\text { Asero, V. \& Patti, S. (2009). From Wine Production to Wine Tourism Experience: the Case } \\
\text { of Italy. American Association of Wine Economists, in http://www.wine-econom- } \\
\text { ics.org/workingpapers/AAWE_WP52.pdf, access in 13-01-2015. } \\
\text { Williams, W. \& Kelly, J. (2001). Cultural Wine Tourists: Product Development Considera- } \\
\text { tions for British Columbia's Resident Wine Tourism Market. International Journal of Wine } \\
\text { Marketing (13,3). U.K.: Emerald; 59-76. } \\
\text { Hobsbawn, E. (1996). A revolução francesa. Paz e Terra. }\end{array}$ \\
\hline Documentação & $\begin{array}{l}\text { Fontes escritas (Estratégia Integrada de Desenvolvimento Territorial do Alto Tâmega, 2014; } \\
\text { livros; artigos imprensa; revistas de vinho) } \\
\text { Fotografia (produção investigadores) } \\
\text { Cartografia (CAOP 2013) }\end{array}$ \\
\hline
\end{tabular}

Fonte: Produção própria com base em MatrizPCI (2006) - Matriz Património Cultural Imaterial

\subsection{Modelo dos 6 A's de Buhalis}

O segundo eixo metodológico engloba os Modelos de 6 A's de Buhalis para elencar os recursos endógenos nas diferentes freguesias de Boticas, de modo a transformar a o Vinho dos Mortos como motor de atração enoturístico e driver de desenvolvimento sustentável do território. Na perspetiva do turismo, abordaram- se de forma integrada os atributos identitários principais que podem transformar o Vinho dos Mortos num evento turístico singular e de salvaguarda do Património Cultural Imaterial de Boticas, garantindo a preser-vação deste processo para que não dependa apenas da memória das pessoas e permaneça acessível às gerações futuras.

Modelo dos 6 A's de Buhalis (2003) per- 
mite elencar os recursos endógenos do território e descobrir os drivers de desenvol-vimento sustentável, tais como: 1.Atrações (naturais ou artificiais), 2.Acessibilidades (Sistema de transportes), 3.Amenidades (oferta retalhista e outros serviços turísticos), 4.Alojamento, 5.Available Packages (pacotes Turísticos) e 6.Auxiliares (Serviços auxiliares: bancos, telecomunicações, etc...). Para além dos elementos mencionados, há ainda a necessidade de considerar a utilização dos recursos pela população e os mercados nacionais e internacionais de turistas, ou seja, a procura.

Importa sustentar a propostas de criação de valor na experiência de Enoturis-mo com os recursos associados ao patrimó-nio cultural de Boticas, visando a sustenta-bilidade do turismo nesses territórios, o envolvimento das comunidades na transmis-são dos seus valores culturais e implementar medidas políticas de planeamento, para garantir a memória e manutenção desses recursos. Assim, baseados no modelo conce-ptual de Buhalis, serão elencados alguns dos recursos endógenos que poderão servir de "matéria-prima" na construção da oferta turística, de modo a transformar Boticas num destino de enoturismo singular.

\subsubsection{Atrações}

Não querendo ser exaustiva, elen-cam-se algumas das atrações deste territó-rio. Recursos Endógenos gastronómicos - Produtos DOP (denominação Origem Protegida): o Mel do Barroso e a Carne Barrosã e Produtos com Indicação Geográfica (IG): Fumeiro de Boticas IG (dos enchidos fazem parte a alheira, a bucheira, o chouriço azedo de farinha, o chouriço de abóbora, a farinhota, a linguiça de carne, o salpicão e a sangueira) e Panificação de Boticas IG (broa de centeio ou broa centeia, pelo folar e pela bica ou bola de carne).

Recursos Endógenos naturais: Patrimô- nio Natural: Boticas Parque - Natureza e Biodiversidade

(http://www.boticasparque.pt/dados.php?ref=a presentacao-parque) que abrange as freguesias de Vilar, Codessoso e Beça. A rápida ligação à autoestrada A24 confere-lhe boas acessibilidades, tanto de Espanha (Galiza) como do Norte de Portugal. O Parque é atravessado pelo rio Beça, que apresenta uma vasta mata ripícola, com proteção dos habitats com enorme valor natural (florísticos, faunísticos e fungos).

\section{Recursos Endógenos culturais -}

Património Cultural (material e imaterial): Repositório histórico do "VINHO DOS MORTOS" (https://www.cm-

boticas.pt/conteudos/default.php?id=1), Museu Rural de Boticas (https://www.cmboticas.pt/conteudos/default.php?id=2), Centro de Artes Nadir Afonso; o Centro de Interpretação do PAVT- Parque Arqueológico do Vale do Terva - Bobadela - Boticas (localiza-se na aldeia de Bobadela - Boticas e funciona como lugar de conhecimento, proporcionando uma exposição permanente que apresenta as características e história do território do PAVT, facultando ao visitante informação que lhe permitirá partir à descoberta da paisagem cultural do vale superior do rio Terva).

No aspecto histórico, o concelho possui um vasto património, enriquecido por uma grande variedade de vestígios de povoações castrejas. Com destaque para a figura emblemática do Guerreiro Calaico, um dos achados provenientes dos Castros de Boticas, expoente da estatuária castreja com profundo enraizamento popular e institucio-nal que, por esse motivo, constitui hoje uma aposta forte do Município no que respeita à promoção e divulgação da sua imagem.

Património Edificado - Fornos comunitários (Forno do Povo de Alturas do Barroso, Forno do Povo de Atilhó, Forno do Povo de Vilarinho Seco); cruzeiros, moinhos, capelas 
[Capela de Nossa Sra. de Fátima (Alturas do Barroso); Capela de Sampaio (Vilarinho Seco); Capela de Santa Margarida (Atilhó) - Património Classificado (IIM)]; Casas de Vilarinho Seco; Igreja Paroquial de Santa Maria Madalena (Alturas do Barroso); Relógio de Sol (Vilarinho Seco); Casas com cobertura de colmo; Miradouros Naturais da Serra do Barroso; Parque de Lazer de Peade (Alturas do Barroso).

Património arqueológico - Foram identificados 24 castros no concelho, o que atesta bem a expansão da cultura castreja neste território. Esses castros encontram-se "implantados em montes ou cabeços, mais ou menos altos, quase sempre junto ou na proximidade dum rio, ou ribeiro, e muitas vezes na confluência de cursos de água" (Santos Júnior et al., 1983:402). Indicam-se os seguintes: Castro de Vilarinho Seco / Mena / Couto ou Côto dos Mouros (em Vilarinho Seco); Castro do Côto dos Corvos (em Alturas do Barroso); Castro de Cunhas (em Ardãos); Castro da Gorda ou Castro da Murada da Gorda (em Ardãos); Castro da Malhó ou de Amalhó (em Ardãos); Castro de Carvalhelhos (Património Classificado - IIP) em Carva-Ihelhos (Beça); Castro da Torre ou Torre de Seirrãos em Seirrãos (Beça); Castro do Brejo ou Cidadonha, em Bobadela; Castro de No-gueira em Nogueira (Bobadela); Castro do Alto da Coroa / Castro da Naia / Rio Mau, em Codessoso; Castro do Poio, em Covas do Barroso; Castro de Ervas Ruivas / Areais, em Lousas (Dornelas); Castro de Gestosa ou Souto da Lama, em Gestosa (Dornelas); Castro do Cabeço em Granja; Castro do Mouril, em Pinho; Castro do Lesenho em Campos (S. Salvador de Viveiro); Castro do Muro / Casas dos Mouros em Sapiãos; Castro do Muro ou da Cerca, em Sapelos (Sapiãos); Castro de Sapelos em (Sapiãos); Alto do Crasto / Castelo dos Mouros, em Vilar; Mamoa da Pedra do Sono / Pedra do Sono; Mamoa de Chã do Seixal / Chã do Seixal; Calçada Romana / Via; (...)Festas e Romarias: S. Sebastião, 20 de Janeiro, Alturas do Barroso; S. Sebastião, Domingo a seguir ao dia 20 de Janeiro, Atilhó; Santa Cruz, 03 de Maio, Vilarinho Seco; Sto António, 13 de Junho, Alturas do Barroso e Atilhó; Santa Maria Madalena, 26 de Junho, Alturas do Barroso; S. Paio, 26 de Junho, Vilarinho Seco; Santa Ana, 26 de Julho / início de Agosto, Alturas do Barroso; Santa Margarida, último domingo de Agosto, Atilhó; Santa Bárbara, 04 de Dezembro, Atilhó; Santa Luzia, 13 de Dezembro, Atilhó; Santo André, Último Domingo de Maio e Nossa Sra. das Neves, 3o ou 4으 domingo de Agosto, em Ardãos; .

\subsubsection{Acessibilidades}

O concelho de Boticas é servido por uma rede viária com 3 auto-estradas (A23, A52 e A47), o que facilita o acesso das principais cidades portuguesas do Norte e Espanholas vizinhas (entre 1 a 2,5 horas), como se observa na Figura 4.

Boticas encontra-se acessível por rede viária, sensivelmente à mesma distância de Madrid e Lisboa e perto de grandes cidades como Orense, Vigo, Santiago de Compostela, Vila Real, Braga e Porto. Na região Norte onde se enquadra Boticas os Fluxos de passageiros no Aeroporto Sá Carneiro (Porto) foram de 4003,3 (milhares de passageiros) e nos Portos Marítimos de 78499 passageiros. 
Figura 4 - Acessibilidades ao Concelho de Boticas

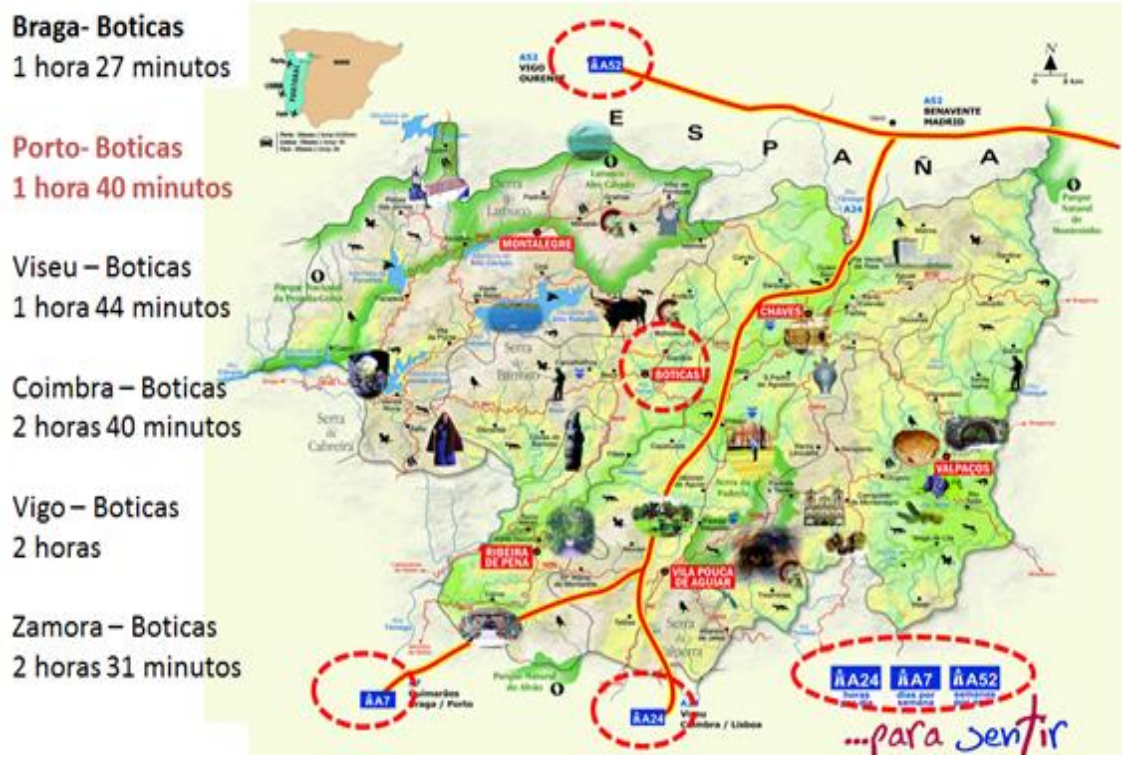

Fonte: http://cimat.pt/wp-content/uploads/2015/02/mapa.jpg

\subsubsection{Amenidades}

O concelho de Boticas possui um conjunto de amenidades como: WC público, Sinalização, lojas de produtos tradicionais, Restaurantes e cafés, postos de turismo, Telecomunicações acessíveis, Serviços de emergência, entre outras, repartidas de forma desigual pelas povoações da região. Portanto, Boticas é célebre pela Gastronomia, nomeadamente pela carne de vitela "barrosã", mas também pelo afamado "vinho dos mortos", que conseguiu este designação desde tempos das invasões Francesas.

\subsubsection{Alojamento}

O concelho dispõe de unidades hoteleiras diversificadas (1 Albergaria; 1 estalagem; 3 Turismo Rural; 2 residenciais; 1 parque de campismo; 4 abrigos de montanha), espalhadas por algumas freguesias do concelho, procurando responder aos diferentes tipos de turismo existentes com especial relevo para o turismo de montanha, turismo de saúde, turismo em espaço rural e ecoturismo, que têm registado nos últimos anos uma crescente procura.

\subsubsection{Available Packages}

É possível obter um guia de viagem para boticas através de vários sítios na internet, tais como: no minube (http://www.minube.pt/oque-ver/portugal/norte/boticas); no Tripadvisor (https://www.tripadvisor.pt/Attractionsg2199643-Activities-

Boticas Vila Real District Northern Portugal.h tml); no Guia da cidade (https://www.guiadacidade.pt/pt/poi-boticas15815); no hotelriobeca (http://www.hotelriobeca.com/wpcontent/uploads/2013/09/Visitar-no-Concelhode-Boticas.pdf); no visitarportugal (https://www.visitarportugal.pt/distritos/d-vilareal/c-boticas); no IGOGO (http://www.igogo.pt/pontos-turisticosboticas/), entre outros.

\subsubsection{Ancillary Services (Serviços auxiliares)}

O concelho de Boticas, especialmente nos centros urbanos possui alguns serviços que podem tornar mais fácil a vida dos turistas, tais como empresas de aluguer de carros, empresas 
de catering, entretenimento: bares, discotecas, serviços de câmbio, seguros, serviço de lavandaria e serviços de marketing turístico. Este modelo explica que um destino deve equilibrar os objetivos estratégicos de todos os stakeholders, bem como a sustentabilidade dos recursos locais. Os destinos precisam diferenciar os seus produtos e desenvolver parcerias entre os setores público e privado localmente, a fim de oferecer uma oferta turística única. Aproveitar os recursos endógenos singulares de Boticas permite que 0 destino aumente a sua competitividade, incrementando a sua visibilidade, reduzindo os custos e reforçando a cooperação local. Os destinos de hoje operam em ecossistemas complexos, integrando dentro de suas estratégias de desenvolvimento, competição e cooperação (coopetition), ligando uma grande diversidade stakeholders. A abordagem da coopetição no Enoturismo é considerada uma estratégia adequada, permitindo a integração dos sectores primário (agricultura), secundário (indústria vitivinícola) e terciário (turismo), integrando os atributos culturais e paisagísticos e aproveitando as competências de parceria e as sinergias dos stakeholders. O sucesso do ecossistema de turismo de vinho de Boticas reside na harmonia de objectivos e interesses de todos os stakeholders, quer na criação de produtos turísticos inovadores (para obter competitividade nos negócios), ou no desenho de actividades e experiências, que promovam a descoberta e interpretação da paisagem associada à cultura do vinho (para entregar autenticidade), e fomentar o desenvolvimento regional (para construir a sustentabilidade).

\section{CONCLUSÕES - INCORPORAR DINÂMICAS CULTURAIS NAS ROTAS DO VINHO}

O desenvolvimento do Enoturismo, numa região vitivinícola, apresenta benefícios não só para os vitivinicultores, caves e adegas, como também para a comunidade local e ainda como destino turístico (Getz,2000). Sendo o património cultural de Boticas associado à cultura do "vinho dos mortos" um elemento fundamental da identidade daquela comunidade, a sua salvaguarda poderá constituir uma forma de preservar a diversidade cultural face à globalização. Num mundo em rápida mudança, os sentimentos de perda e de instabilidade tornam o património cultural uma âncora assumindo uma especial urgência a sua conservação como forma de garantir a diversidade, o pluralismo cultural e o acesso à cultura (Mason e Torre 2000, p.171). No sector do Enoturismo em Boticas algo semelhante poderia ocorrer.

Para garantir sucesso das dinâmicas culturais associadas ao Enoturismo do concelho de Boticas será necessário desenvolver estratégias de coopetição. Este conceito foi popularizado por Brandenburger \& Nalebuff (1996), propondo um modelo de coopetição baseado na capacidade de uma organização formar redes de valor, procurando entender e identificar as interdependências dos fatores e dos players. No que respeita ao desenvolvimento do território de Boticas, várias perspetivas podem ser observadas, seguindo as propostas de Lado et al. (1997) que observou a coopetição sob o ponto de vista da procura conjunta por recursos e capacidades. Para estes autores a coopetição está associada à competição, e o sincronismo estratégico entre ambas levaria os stakeholders a obterem maior sucesso nas suas dinâmicas, comparativamente ao resultado obtido, se a competição ou a cooperação fossem usadas isoladamente. Por seu turno, Bengtsson e Kock (2000) apresentam um modelo de coopetição baseado em graus de relacionamentos coopetitivos. Para as autoras, as organizações tendem a competir nas ações mais próximas dos clientes (área comercial) e cooperar naquelas 
mais afastadas (produção). Associando ao Enoturismo, o trabalho em rede é vantajoso para todos os intervenientes, pois o vinho como um produto cultural tem grande relevância para o desenvolvimento, valorização e promoção dos territórios.

Assim, este projecto terá continuidade através da auscultação dos players do ecossistema do turismo vitivinícola quanto à identificação e gestão de questões específicas relacionadas com os recursos endógenos da indústria vitivinícola, do sector turístico, do património e dos seus impactes específicos.

\section{REFERÊNCIAS}

Asero, V. \& Patti, S. (2009). From Wine Production to Wine Tourism Experience: the Case of Italy. American Association of Wine Economists, Disponible in: http://www.wine-economics.org/workingpapers/AAWE_WP52.pdf, access in 13-01-2015.

Bengtsson, M. e Kock, S. (1999). Cooperation and Competition in relationships between competitors in business networks. The Journal of Business \& Industrial Marketing, 14(3), pp.178-196.

Bradenburger, A.M. e Nalebuff, B.J. (1996). Coopetition. New York: Doubleday.

Brunet, R.,(1990). Le territoire dans-les turbulences. Paris: Reclus, p.224.

Buhalis, D. (2003). eTourism: information technology for strategic tourism management. Pearson (Financial Times/Prentice Hall), London ISBN 0582357403

CAOP - Carta Administrativa Oficial de Portugal, 2016. Disponible: http://www.dgterritorio.pt/cartografia_e_geodesia/cartografia/carta_administrativa_oficial_de_portugal_caop_/caop_em_vigor/. Acesso 23-12-2016.

Carlan, C. (2012). Vinho: Comércio e Poder no Mundo Antigo. In: Candido, Maria Regina (Org.)

Chuck Y. (1997). International Tourism: a Global

Perspective. World Tourism Organization (WTO) Publications, Madrid.
Cole, S. T., \& Chancellor, H.C. (2009). Examining the festival attributes that impact visitor experience, satisfaction and re-visit intention. Journal of Vacation Marketing, 15, pp. 323-333.

Cooper, C., \& Hall, C., M. (2008). Contemporary Tourism. Routledge Taylor \& Francis Group.

Costa, A. (2007). O Enoturismo em Portugal: o caso das Rotas do Vinho. Revista da Ciência da Administração, 1, jan./jun. Universidade de Pernambuco: versão electrónica.

Deloitte Vintur Project (2005). European Enotourism Handbook. Project: "VINTUR".

Demangeon, Albert (1982). Uma definição da Geografia Humana. In: Christofoletti, Antonio (Org.). Perspectivas da Geografia. São Paulo: Difel.

European Charter on Oenotourism (2006). http://www.recevin.net/userfiles/file/VINTUR/ Charte_EN.pdf, accessed in 2-10-2015.

Eusébio, C., Kastenholz, E. \& Breda, Z. (2016). Tourism and Sustainable Development of Rural Destinations. In: Kastenholz, E., Carneiro, M.J., Eusébio, C. \& Figueiredo, E. (Ed) 2016. Meeting Challenges for Rural Tourism through Co-Creation of Sustainable Tourist Experiences. Cambridge Scholars Publishing

Getz, D. (2000). Explore Wine Tourism: management, development \& destinations. Cognizant Communication Corp.

Goeldner, R. and Ritchie, B. (2006). Tourism: Principles, Practices, Philosophies. Hoboken (NJ), John Wiley \& Sons, (10th ed.).

Hill, M. e Hill, A. (2000). Investigação por Questionário. Lisboa: Edições Sílabo, Lda.

Hobsbawn, E. (1977). A era das revoluções. Ed. Paz e Terra, pp.71-95.

Hobsbawn, E. (1996). A revolução francesa. Ed. Paz e Terra.

Howley, M. \& Westering, J. (2008). Developing wine tourism: A case study of the attitude of English wine producers to wine tourism . Journal of Vacation Marketing , 14(1), pp. 87-95.

Inácio, A. (2008). O Enoturismo em Portugal: da "Cultura" do vinho ao vinho como cultura. Universiadde 
de Lisboa, Faculdade de Letras. Departamento Geografia. Tese doutoramento.

INE, I. P., (2015). Anuário Estatístico da Região Norte. Statistical Yearbook of Norte Region 2015. Statistics Portugal.

Jollivet, M. \& Pavé, A.,. O meio ambiente: questões e perspectivas para a pesquisa. In: Vieira, P.F. \& Weber, J. (orgs) Gestão de recursos naturais renováveis e desenvolvimento. Novos desafios para a pesquisa ambiental. São Paulo: Cortez, 2000, p. 115-146. 2000.

Kastenholz, E., Eusébio, C., Figueiredo, E., Lima, j. (2014). Reinventar o turismo rural em Portugal - cocriação de experiências turísticas sustentáveis. UA Editora - Universidade de Aveiro, Serviços de Biblioteca, Informação Documental e Museologia.

Kuper, A. (1999). Culture: the anthropologist's account. Cambridge: Harvard University Press.

Lado, A. A., Boyd, N. G., Hanlon, S. C. (1997). Competition, Cooperation, and the Search for Economic Rents: a syncretic model. Academy of Management Review, 1, pp.110-141.

Lefebvre, Henri (1976). Espacio y Política. Barcelona: Peninsula.

Mason, R., \& Torre, M. (2000). Valores e conservação do património nas sociedades em processo de globalização. Informe Mundial sobre a Cultura 2000, Brasil, São Paulo: UNESCO/Editora Moderna Lda., pp.170-186.

Matos, M., (2013). Governança e Políticas Públicas em Territórios de Baixa Densidade. Dissertação de Mestrado. Lisboa: ISCTE-IUL. Acessível em https://repositorio.iscte-iul.pt/bitstream/10071/7357/1/Dissertacao\%20Concei\%C3\%A7aoMatos\%20-\%20Governan\%C3\%A7a\%20e\%20PP\%20em\%20TBD \%20\%20Sem\%20CV.pdf.

Montanari, M. (2008). Sistemas Alimentares e Modelos de Civilização. In Flandrin, J. (coord.) e Montanari, M., História da alimentação: dos primórdios à Idade Média. 2. ed., Lisboa, Terramar, pp. 91-101.

Moreira, Ruy (1982). Repensando a Geografia. In: SANTOS, Milton (Org.). Novos rumos da Geografia brasileira. São Paulo: Hucitec.
Moutinho, R. \& Manso, J. (2015). Políticas Públicas para os territórios de baixa densidade no contexto da agenda 2020. In: P. Neto \& M. M. Serrano (Ed.), Políticas Públicas, Economia e Sociedade (pp.313347). Alcochete: Smartbook.

Oliveira Jorge, V. (2005). Espaço, meio, paisagem, território, região e lugar na experiência de um arqueólogo: alguns contributos reflexivos. Trabalhos de Antropologia e Etnologia. 45, 159-172.

Oliveira, A., Rodrigues, A., \& Cantanhede, F. (2005). História e Geografia de Portugal 6o ano, v. 2, Lisboa, Texto Editora,p. 33.

Pecqueur, B.,(2000). Qualite et développement L'hypothese du panier de biens. In: Symposium sur le développement regional. INRA-DADP. Montpellier.

Saayman, M., \& van der Merwe, A. (2014). Factors determining visitors' memorable winetasting experience at wineries. Anatolia: An International Journal of Tourism and Hospitality Research, 26 (3), 372-383.

Sabourin E. (2002). In: Sabourin Eric (ed.), Teixeira Olivio Alberto (ed.). Planejamento e desenvolvimento dos territorios rurais : Conceitos, controvérsias e experiências. Petrolina: EMBRAPA, p. 21-37.

Salvado, J.O.M.G. (2016). Enotourism ecosystem: stakeholders'coopetition model proposal. Tourism and Hospitality International Journal, 6(2), 77-93. In http://www.isce-tur-

ismo.com/static/files/5d707f90-THIJ-vol-6-n-2.pdf.

Santos, Milton (1999). A natureza do espaço: técnica e tempo, razão e emoção. 3 ed. São Paulo: Hucitec.

Santos, N., e Cunha, L. (2008). Novas oportunidades para o espaço rural. Análise exploratória no Centro de Portugal. In: N. Santos e A. Gama. Lazer. Da libertação do tempo à conquista das práticas. Coimbra: Imprensa da Universidade, pp. 209-225.

Silva, A., Lima, F. \& Chamusca, P., (2010).

Estratégias de eficiência colectiva em territórios de baixa densidade: reflexões a propósito do MinhoLima e do Tâmega. XII Colóquio Ibérico de Geografia, 3-8. Acessível em http://web.letras.up.pt/xiicig/comunicacoes/151.pdf.

Silva, J. (2012). Primeira Invasão Francesa 1807-1808 : A invasão de Junot e a revolta popular. Instituto estudos académicos para seniores. Academia das $\mathrm{Ci}$ ências de Lisboa ( $A C L)$, 
TP-Turismo de Portugal (2015). Estudo Satisfação do Turista no Iverno 2015. http://www.turismodeportugal.pt/Português/ProTurismo/estatísticas/EstudosdeSatisfacaodosTuristas/Documents/Inquérito\%20a\%20Turistas\%20Cl vaga\%20inverno\%202015.pdf.

TP-Turismo de Portugal, (2013). Plano Estratégico para o Turismo. Lisgráfica, Impressão e Artes Gráficas, S.A. Lisboa.

Unesco (2006). The Intangible Heritage Messenger, n. 1, Paris, UNESCO, Fev. 2006.

http://unesdoc.unesco.org/images//0014/001445/144569e.pdf . Acesso em 1212-2015).

Urry, J. (1999). O Olhar do Turista: Lazer e Viagens nas Sociedades Contemporâneas. 2. Ed. Studio Nobel/SESC: São Paulo.

Williams, P. (2001). The evolving images of wine tourism destinations. Tourism Recreation Research, 26 (2), 3-10.

\section{REFERÊNCIAS DA WEB}

Anuário do IVV 2011 in http://www.vinetowinecircle.com/regioes/transmontano/

Boticas Parque - Natureza e Biodiversidade in http://www.boticasparque.pt/dados.php?ref=apresentacao-parque

Comunidade Intermunicipal do Alto Tâmega (CIMAT) in http://cimat.pt/wp-content/uploads/2015/02/mapa.jpg

Estratégia Integrada de Desenvolvimento Territorial do Alto Tâmega (DEZEMBRO 2014) in http://adrat.pt/wp-content/uploads/2016/02/EstrategiaAT.pdf, acesso 22-março 2017

Guia da cidade (https://www.guiadacidade.pt/pt/poi-boticas-15815)

hotelriobeca (http://www.hotelriobeca.com/wpcontent/uploads/2013/09/Visitar-no-Concelhode-Boticas.pdf)
IGOGO (http://www.igogo.pt/pontos-turisticosboticas//,

INE (2012) Census 2011. https://www.ine.pt/INE (2012). Censos 2011. In http://censos.ine.pt/xportal/xmain?xpid=CENSOS\&xpgid=censos2011 ecensos. Acesso 1 Janeiro 2017.

minube (http://www.minube.pt/o-que-ver/portu$\mathrm{gal} /$ norte/boticas);

Museu Rural de Boticas in https://www.cm-boticas.pt/conteudos/default.php?id=2

Portaria no $1203 / 2006$ in https://www.ivdp.pt/pt/docs/legislacao/236.pdf

Portaria no $1204 / 2006$ in https://www.ivdp.pt/pt/docs/legislacao/237.pdf

Repositório histórico do "VINHO DOS MORTOS" (https://www.cm-boticas.pt/conteudos/default.php?id=1

Revista Dinheiro Vivo in WWW.Dinheirovivo.pt/topico/vinhos/

Sorocaba e Jundiaí in http://g1.globo.com/saopaulo/sorocaba-jundiai/noticia/2016/05/tradicaodo-vinho-dos-mortos-e-atracao-deste-sabadoem-sao-roque.html

Tripadvisor (https://www.tripadvisor.pt/Attractions-g2199643-Activities-Boticas Vila Real District Northern Portugal.html)

visitarportugal (https://www.visitarportugal.pt/distritos/d-vila-real/c-boticas)

\section{Dados da autora}

\section{Josefina Olívia Salvado}

Doutora em Turismo pela Universidade de Aveiro (UA). Investigadora da GOVCOPP - Unidade de Investigação Governança, competitividade e Politicas Públicas da Universidade de Aveiro Email: josefina.o.salvado@gmail.com 